\title{
Effects of Sucrose and Other Additives on In Vitro Growth and Development of Purple Coneflower (Echinacea purpurea L.)
}

\author{
Dahanayake Nilanthi ${ }^{1}$ and Yue-Sheng Yang ${ }^{2}$ \\ ${ }^{1}$ Department of Agricultural Biology, Faculty of Agriculture, University of Ruhuna, Mapalana, Kamburupitiya 81100, Sri Lanka \\ ${ }^{2}$ Genetic Engineering Laboratory, College of Life Sciences, South China 510642, China
}

Correspondence should be addressed to Dahanayake Nilanthi; daha_27@yahoo.com

Received 20 February 2014; Revised 26 May 2014; Accepted 3 June 2014; Published 16 June 2014

Academic Editor: Stefan Liebau

Copyright @ 2014 D. Nilanthi and Y.-S. Yang. This is an open access article distributed under the Creative Commons Attribution License, which permits unrestricted use, distribution, and reproduction in any medium, provided the original work is properly cited.

Echinacea purpurea (purple coneflower) is being used for the preparation of more than 240 extracts, salves, and tinctures to help cure diseases like rabies, cold, and upper respiratory infections. Hence, efforts were made to develop a culture medium for successful in vitro culturing of cornflower and to regenerate buds and induce roots to enable mass propagation of selected clones. Of the three levels of sucrose tested as a supplement to MS media (Murashige and Skoog's medium, 1962) 3\% showed better rooting of buds and appeared morphologically normal and identical as compared to those grown at higher and lower concentrations ( 2 and $4 \%)$. The additives hydrolyzed lactabumin $\left(0.0,100,300\right.$, and $\left.900 \mathrm{mgL}^{-1}\right)$, peptone $\left(0.0,100,300\right.$, and $\left.900 \mathrm{mgL}^{-1}\right)$, and yeast $(0.0$, 100,300 , and $900 \mathrm{mgL}^{-1}$ ) to media containing $0.3 \mathrm{mgL}^{-1} \mathrm{BA}$ (6-benzyladenine) and $0.01 \mathrm{mgL}^{-1} \mathrm{NAA}$ (naphthaleneacetic acidplant growth regulators) has negatively influenced proliferation of shoots. The higher concentrations of the above have delayed the development of plantlets. Shoot multiplication was enhanced by coconut water with $2 \%$ being the best among 4 and $8 \%$ tested. Shoot organogenesis was not influenced by copper sulphate $\left(0,1.5,3,6\right.$, and $\left.12 \mathrm{mgL}^{-1}\right)$ and silver nitrate $\left(0.0,0.5,2.5\right.$, and $\left.12.5 \mathrm{mgL}^{-1}\right)$ supplements and at higher concentrations of the above inhibited plant growth.

\section{Introduction}

Large-scale in vitro propagation medicinal plants have become vital to meet the increasing demand for high-quality pharmaceuticals and for the conservation of valuable elite stock plants [1-4]. Echinacea purpurea (purple coneflower) is known to contain carbohydrates, glycosides, alkaloids, alkylamides (alkamides), polyacetylenes, fatty acids, essential oil, and phytosterols and is being used for the preparation of more than 240 extracts, salves, and tinctures to help cure diseases like rabies, cold, upper respiratory infections, and so forth (http://www.bioalma.com/). Hence, efforts were made to develop a culture medium for successful in vitro culturing of cornflower and to regenerate buds and induce roots to enable mass propagation of selected clones.

\section{Materials and Methods}

2.1. Plant Source. Seeds for the present study were harvested from the purple cornflower clone (source: Norton, MA, USA) maintained at the Chinese Medicinal Plant Garden, South China Agricultural University.

2.2. Establishment of Aseptic Seedlings. Seeds were surfacesterilized by sequentially immersing in $70 \%$ ethanol for 1 minute, $0.1 \%$ mercuric chloride for 10 minutes, and $1 \%$ sodium hypochlorite (containing Tween 20, one drop per $50 \mathrm{~mL}$ ) for 10 minutes. Sterilized seeds were then rinsed three times in sterilized-deionized water and inoculated on a sterilized medium composed of half-strength MS salts, $1 \%$ sucrose $500 \mathrm{mgL}^{-1}$ hydrolyzed lactalbumin and $0.2 \%$ phytagel (solidifier). 
TABLE 1: Weight (g) of plant parts of purple coneflower grown under different sucrose concentrations $(n=8)$.

\begin{tabular}{lccccc}
\hline Sucrose conc. \% & Whole plant & Leaves & Petiole & Roots & $0.38^{\mathrm{ab}}$ \\
\hline 2 & $1.26^{\mathrm{ab} *}$ & $0.42^{\mathrm{a}}$ & $0.30^{\mathrm{a}}$ & $0.10^{\mathrm{ab}}$ \\
3 & $1.69^{\mathrm{a}}$ & $0.56^{\mathrm{a}}$ & $0.36^{\mathrm{a}}$ & $0.61^{\mathrm{a}}$ & $0.12^{\mathrm{a}}$ \\
4 & $0.77^{\mathrm{b}}$ & $0.35^{\mathrm{a}}$ & $0.19^{\mathrm{a}}$ & $0.14^{\mathrm{b}}$ & $0.05^{\mathrm{b}}$ \\
\hline
\end{tabular}

* Means followed by the same lower case letters in each column are not significantly different at $5 \%$ level in Duncan's Multiple Range Test.

After $14 \mathrm{~d}$ under dim light, the germinated seeds were transferred to a sterilized medium containing full-strength MS salts, $1 \%$ sucrose, $0.2 \%$ phytagel, and $0.6 \%$ agar. Seedlings cultures were then incubated in a room at $25^{\circ}-27^{\circ} \mathrm{C}$ and $12 \mathrm{~h}$ photoperiod under cool-white light $\left(50 \mu \mathrm{mol} \mathrm{m}^{-2} \mathrm{~s}^{-1}\right)$ for 40 days. All media used were adjusted to the $\mathrm{pH} 6.0$ with $1 \mathrm{~N}$ $\mathrm{NaOH}$ or $1 \mathrm{~N} \mathrm{HCl}$, prior to autoclaving at $1.4 \mathrm{~kg} \mathrm{~cm}^{-2}$ for 20 minutes.

2.3. Effect of Sucrose on Culture Medium on Shoot and Root Growth. Explants of purple coneflower shoots $(1 \mathrm{~cm})$ were introduced to the MS basal medium containing $0.3 \mathrm{mgL}^{-1}$ BA and $0.01 \mathrm{mgL}^{-1} \mathrm{NAA}$ and three concentrations of sucrose $(2 \%, 3 \%$, and $4 \%)$ to assess the shoot growth and root development.

\subsection{Effect of Other Additives on Culture Medium on Shoot} and Root Growth. Explants of purple coneflower petiole were grown in media containing $0.3 \mathrm{mgL}^{-1} \mathrm{BA}$ and $0.01 \mathrm{mgL}^{-1}$ NAA (plant growth regulators) with the following additives hydrolyzed lactalbumin $\left(0.0,100,300\right.$, and $\left.900 \mathrm{mgL}^{-1}\right)$, peptone $\left(0.0,100,300\right.$, and $\left.900 \mathrm{mgL}^{-1}\right)$, yeast $(0.0,100,300$, and $\left.900 \mathrm{mgL}^{-1}\right)$, coconut water $(0,2,4$, and $8 \%)$, copper sulphate $\left(0,1.5,3,6\right.$, and $\left.12 \mathrm{mgL}^{-1}\right)$, silver nitrate $(0.0,0.5,2.5$, and $\left.12.5 \mathrm{mgL}^{-1}\right)$, and proline $\left(0,150,450\right.$, and $\left.1000 \mathrm{mgL}^{-1}\right)$ to evaluate effect of these additives on growth and regeneration of callus explants.

2.5. Data Collection and Analysis. All experiments were replicated four times having 4 explants per culture bottle. The influence of different media on explant growth was estimated through weighing the shoots and roots separately. Statistical analysis was carried out using the Student Newman-Keuls Means Separation Test of SAS (SAS Institute, Cary, NC, 1995).

\section{Results and Discussion}

3.1. Effect of Sucrose on Culture Medium on Shoot and Root Growth. MS media supplemented with 3\% sucrose showed better rooting of buds and appeared morphologically normal roots as compared to those grown at higher and lower concentrations (Figure 1 and Table 1). Sugar has provided the tissue culture plant with carbon in organic form that is not required for those grown from seeds.

3.2. Effect of Other Additives on Culture Medium on Shoot and Root Growth. Nitrogenous additives, hydrolyzed lactalbumin, peptone, and yeast in the medium have negatively
TABLE 2: Potential of shoot regeneration in petiole explants with different concentrations of additives in MS basal medium with $0.3 \mathrm{mgL}^{-1} \mathrm{BA}$ and $0.01 \mathrm{mgL}^{-1} \mathrm{NAA}$.

\begin{tabular}{|c|c|c|}
\hline \multicolumn{2}{|l|}{ Treatment $\mathrm{mgL}^{-1}$} & Number of buds per explant \\
\hline \multirow{4}{*}{ Lactalbumin hydrolysis } & 0 & $2.12^{\mathrm{a}}$ \\
\hline & 100 & $0.95^{\mathrm{b}}$ \\
\hline & 300 & $0.20^{c}$ \\
\hline & 900 & $0.06^{\mathrm{d}}$ \\
\hline \multirow{4}{*}{ Peptone } & 0 & $1.85^{\mathrm{a}}$ \\
\hline & 100 & $0.80^{\mathrm{b}}$ \\
\hline & 300 & $0.31^{\mathrm{c}}$ \\
\hline & 900 & $0.08^{\mathrm{d}}$ \\
\hline \multirow{4}{*}{ Yeast } & 0 & $1.95^{\mathrm{a}}$ \\
\hline & 100 & $0.91^{\mathrm{b}}$ \\
\hline & 300 & $0.28^{\mathrm{c}}$ \\
\hline & 900 & $0.05^{\mathrm{d}}$ \\
\hline \multirow{4}{*}{ Coconut water } & $0 \%$ & $2.05^{\mathrm{a}}$ \\
\hline & $2 \%$ & $2.58^{\mathrm{b}}$ \\
\hline & $4 \%$ & $2.03^{\mathrm{a}}$ \\
\hline & $8 \%$ & $1.91^{\mathrm{a}}$ \\
\hline \multirow{5}{*}{ Copper sulphate } & 0 & $2.00^{\mathrm{a}}$ \\
\hline & 1.5 & $0.10^{\mathrm{b}}$ \\
\hline & 3 & $0.05^{\mathrm{bc}}$ \\
\hline & 6 & $0.01^{\mathrm{bc}}$ \\
\hline & 12 & $0.00^{c}$ \\
\hline \multirow{4}{*}{ Silver nitrate } & 0 & $1.89^{\mathrm{a}}$ \\
\hline & 0.5 & $0.08^{\mathrm{b}}$ \\
\hline & 2.5 & $0.02^{\mathrm{b}}$ \\
\hline & 12.5 & $0.00^{\mathrm{b}}$ \\
\hline
\end{tabular}

${ }^{*}$ Means followed by the same lower case letters in each column are not significantly different at 5\% level in Duncan's Multiple Range Test.

influenced proliferation of shoots. The higher concentrations of the above have delayed the development of plantlets. Shoot multiplication has been enhanced by coconut water with $2 \%$ being the best. Shoot organogenesis was not influenced by copper sulphate and silver nitrate supplements and at higher concentrations of the above inhibited plant growth (Table 2).

3.3. Growth of Callus Derived from Petiole Explants. Callus taken from cell suspension treated with BA and transferred to the MS medium supplemented with $0.6 \%$ agar $+3 \%$ sucrose with $0.1 \mathrm{mgL}^{-1} \mathrm{BA}+0.0 \mathrm{mgL}^{-1}$ proline displayed soft texture and no significant growth. Callus on medium containing 


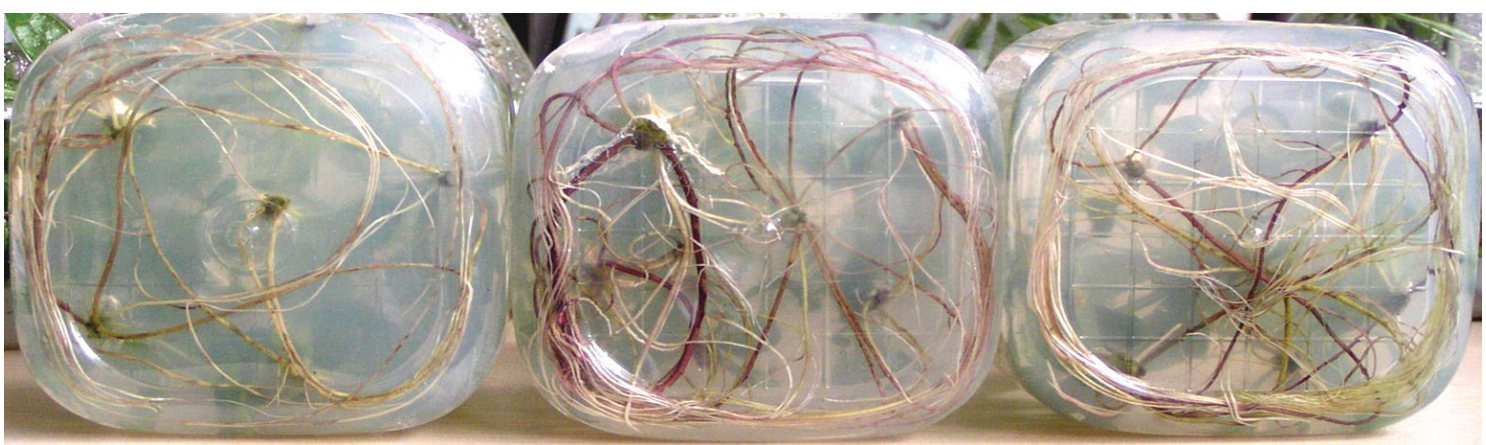

(a)

(b)

(c)

FIGURE 1: Root system of purple coneflower grown under different sucrose concentrations: (a) 4\%; (b) $3 \%$; (c) $2 \%$.

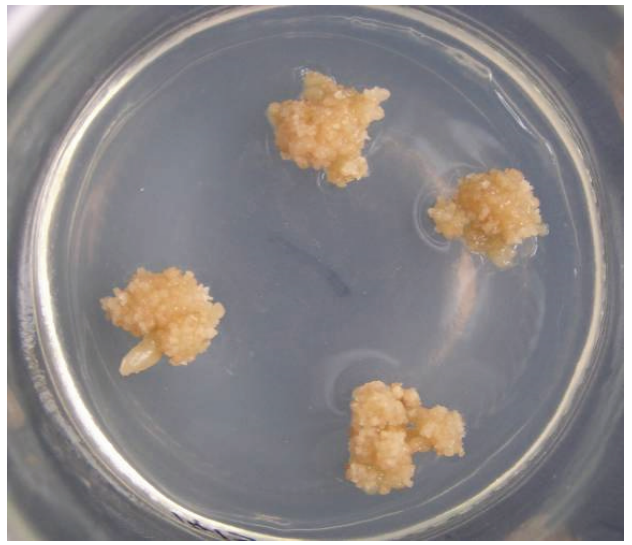

(a)



(c)

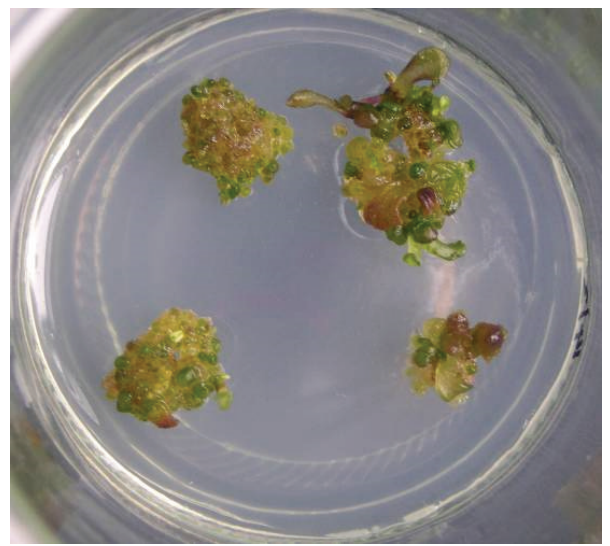

(b)

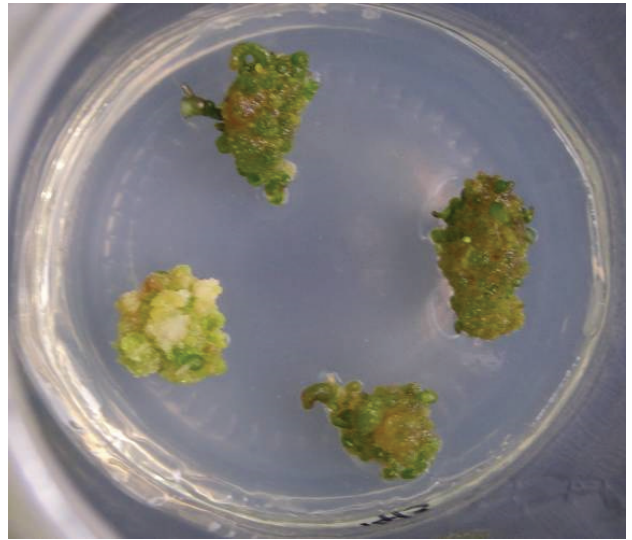

(d)

FIGURE 2: Growth of callus on agar media containing MS basal elements, $3 \%$ sucrose, and other additives: (a) $0.1 \mathrm{mgL}^{-1} \mathrm{BA}^{-1} 0.0 \mathrm{mgL}^{-1}$ proline; (b) $0.1 \mathrm{mgL}^{-1} \mathrm{BA}+150 \mathrm{mgL}^{-1}$ proline; (c) $0.1 \mathrm{mgL}^{-1} \mathrm{BA}+450 \mathrm{mgL}^{-1}$ proline; (d) $0.1 \mathrm{mgL}^{-1} \mathrm{BA}+1000 \mathrm{mgL}^{-1}$ proline. All green buds develop to shoots within 6 weeks.

BA and $150 \mathrm{mgL}^{-1}$ proline showed brownish nodular callus after 9 weeks of initiation. Greenish well growing nodular callus was observed on the medium supplemented with BA and proline at higher concentrations such as $450 \mathrm{mgL}^{-1}$ and $1000 \mathrm{mgL}^{-1}$ (Table 3 and Figure 2).

\section{Conclusion}

Optimum sucrose concentration for shoot growth and root production determined to be $3 \%$ as compared to $4 \%$ and $2 \%$. Greenish well growing nodular callus was observed on the 
TABLE 3: Shoot regeneration in callus explants with different concentrations of proline in MS basal medium with $0.1 \mathrm{mgL}^{-1} \mathrm{BA}$.

\begin{tabular}{lc}
\hline Proline $\mathrm{mgL}^{-1}$ & Number of buds per explant \\
\hline 0 & $0.00^{\mathrm{a}}$ \\
150 & $5.09^{\mathrm{b}}$ \\
450 & $11.9^{\mathrm{c}}$ \\
1000 & $16.7^{\mathrm{d}}$ \\
\hline
\end{tabular}

${ }^{*}$ Means followed by the same lower case letters in each column are not significantly different at $5 \%$ level in Duncan's Multiple Range Test.

medium supplemented with BA and proline at concentration as high as $450 \mathrm{mgL}^{-1}$ and $1000 \mathrm{mgL}^{-1}$. Coconut water (2\%) gave higher shoot regeneration as compared to higher concentrations. Nitrogenous additives, hydrolyzed lactalbumin, peptone, and yeast reduced the proliferation rate of shoots.

\section{Conflict of Interests}

The authors declare that there is no conflict of interests regarding the publication of this paper.

\section{References}

[1] W. Kneifel, E. Czech, and B. Kopp, "Microbial contamination of medicinal plants-a review," Planta Medica, vol. 68, no. 1, pp. 5-15, 2002.

[2] M. R. Beena, K. P. Martin, P. B. Kirti, and M. Hariharan, "Rapid in vitro propagation of medicinally important Ceropegia candelabrum," Plant Cell, Tissue and Organ Culture, vol. 72, no. 3, pp. 285-289, 2003.

[3] S. J. Murch, C. Liu, R. M. Romero, and P. K. Saxena, "In vitro culture and temporary immersion bioreactor production of Crescentia cujete," Plant Cell, Tissue and Organ Culture, vol. 78, no. 1, pp. 63-68, 2004.

[4] M. Vanisree, C.-Y. Lee, S.-F. Lo, S. M. Nalawade, C. Y. Lin, and H.-S. Tsay, "Studies on the production of some important secondary metabolites from medicinal plants by plant tissue cultures," Botanical Bulletin of Academia Sinica, vol. 45, no. 1, pp. 1-22, 2004. 

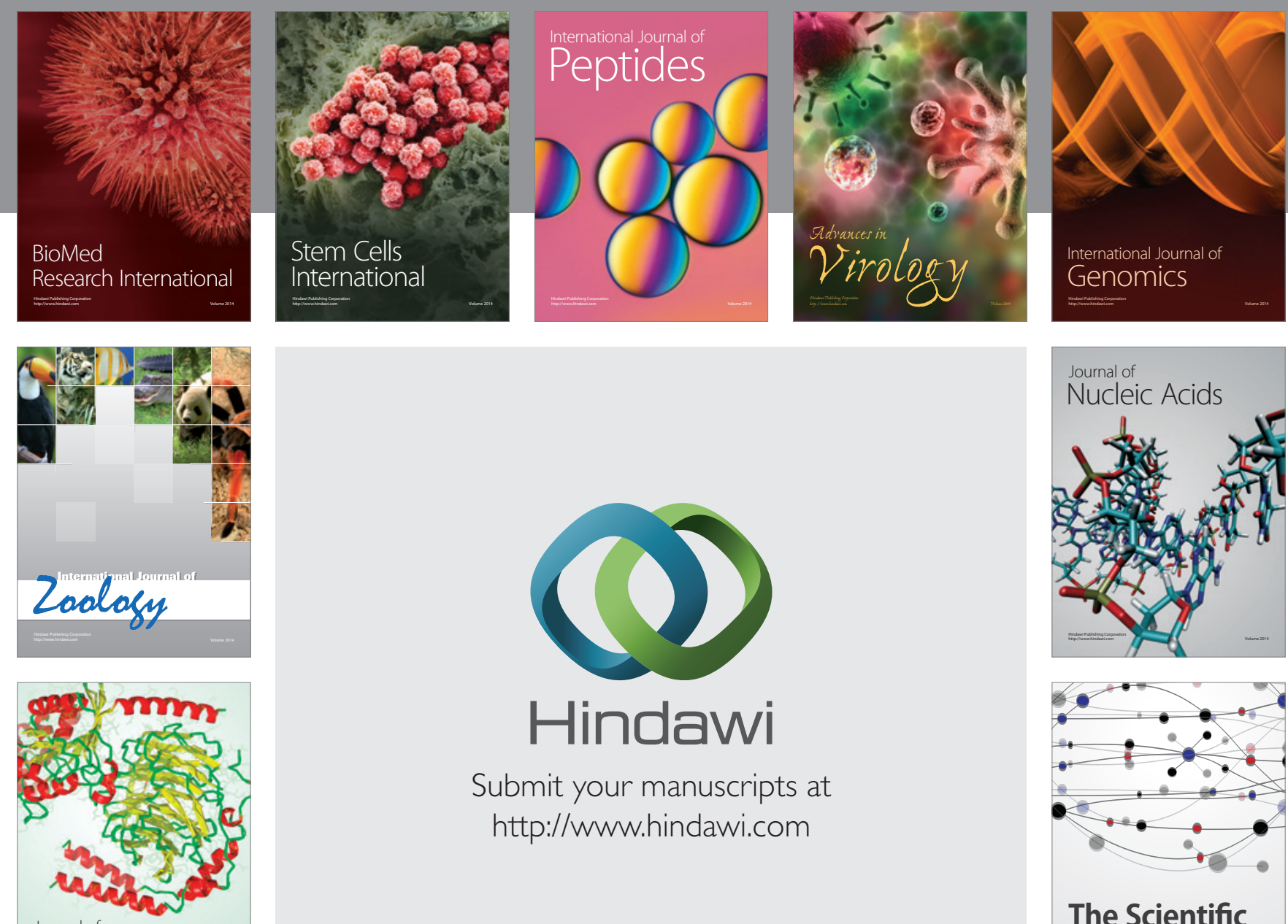

Submit your manuscripts at

http://www.hindawi.com

Journal of
Signal Transduction
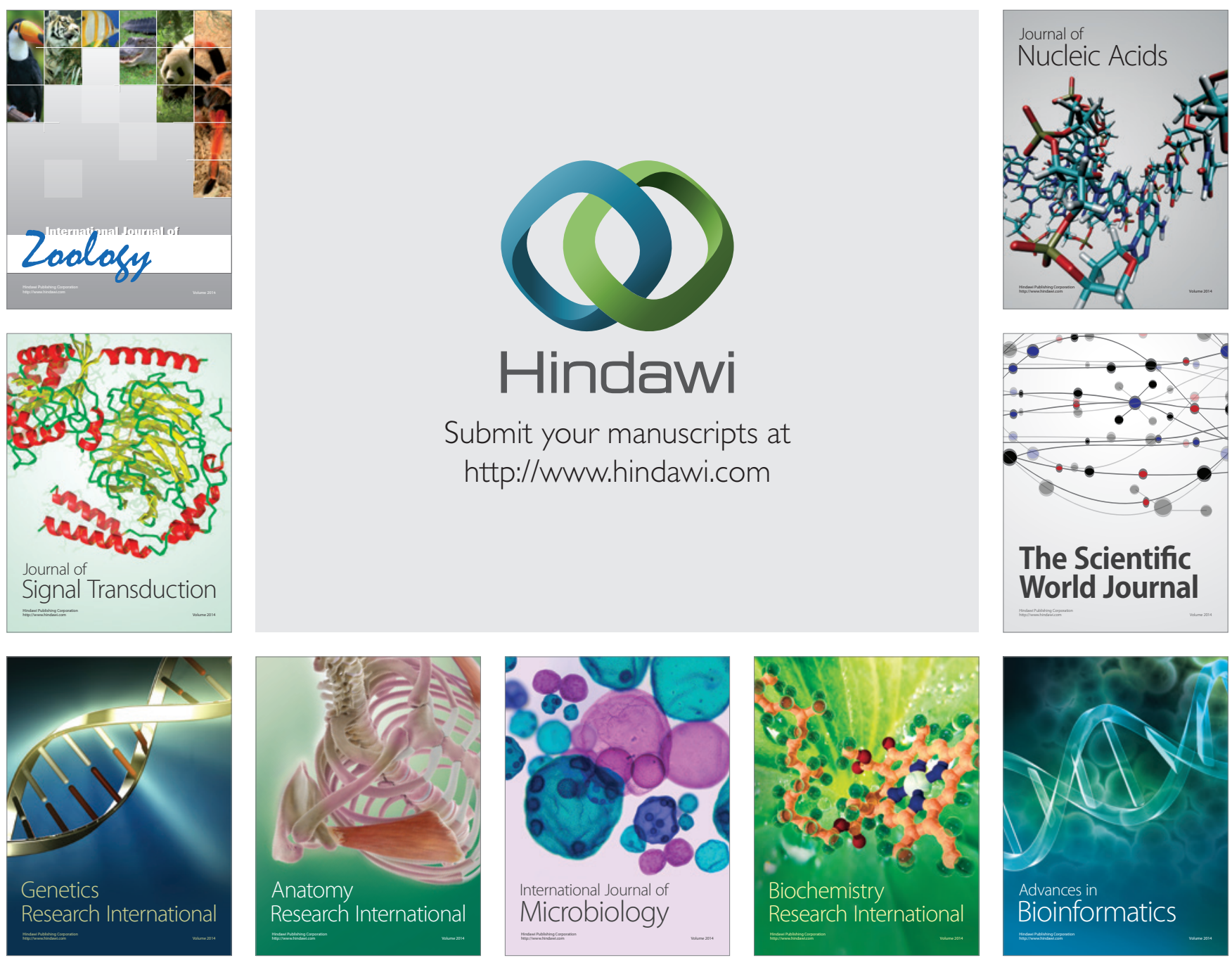

The Scientific World Journal
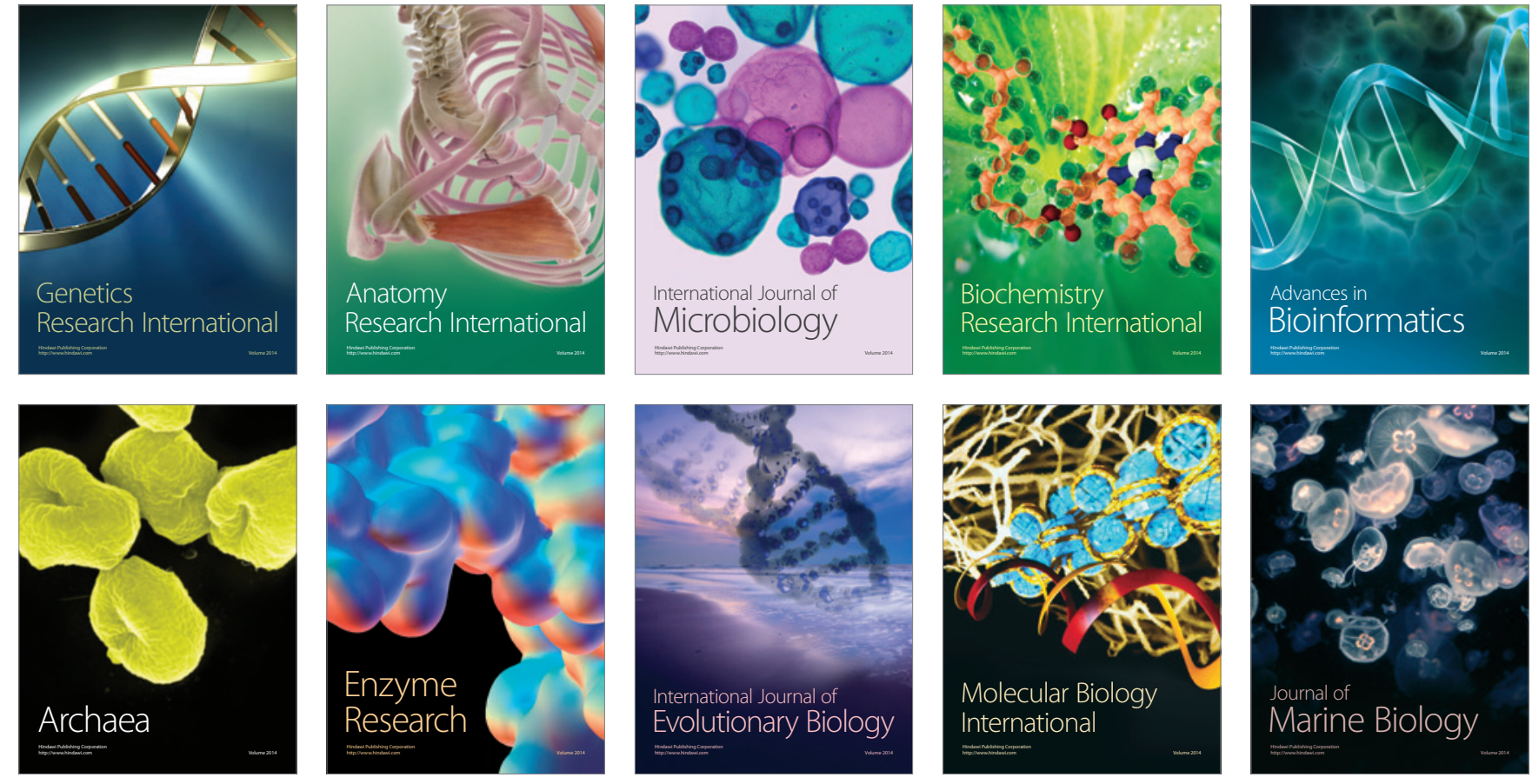